\title{
Medullary Thyroid Carcinoma pT4b TNM Finding v8
}

National Cancer Institute

\section{Source}

National Cancer Institute. Medullary Thyroid Carcinoma pT 4b TNM Finding v8. NCI

Thesaurus. Code C141033.

Very advanced disease; tumor of any size with extension towards the spine or into nearby large blood vessels, invading the prevertebral fascia, or encasing the carotid artery or mediastinal vessels. (from AJCC 8th Ed.) 